\title{
Between Teleophilia and Teleophobia
}

\author{
Eric Schaetzle ${ }^{1} \cdot$ Yogi Hendlin ${ }^{2,3,4}$ \\ Received: 18 March 2021 / Accepted: 6 April 2021 / Published online: 21 April 2021 \\ (C) The Author(s) 2021
}

\begin{abstract}
Denis Noble convincingly describes the artifacts of theory building in the Modern Synthesis as having been surpassed by the available evidence, indicating more active and less gene-centric evolutionary processes than previously thought. We diagnosis the failure of theory holders to dutifully update their beliefs according to new findings as a microcosm of the prevailing larger social inability to deal with competing paradigms. For understanding life, Noble suggests that there is no privileged level of semiotic interpretation. Understanding multi-level semiosis along with organism and environment contrapunctally, according to Jakob von Uexküll's theoretical biology, can contribute to the emerging extended evolutionary synthesis.
\end{abstract}

Keywords Epistemic communities · Teleology $\cdot$ Agency $\cdot$ Networks $\cdot$ Philosophy of science $\cdot$ Evolution

The question of ideology in science has been variously framed, and is germane to understanding shifts in conceptualizing biology, as Denis Noble (2021) articulates in his Target Article. While the so-called "four horsemen" of "new atheism" thought they were ridding science of superstition, many scientists now reflect on this impulse as superstitious clinging to gene determinism in the face of contradictory empirical evidence. While the dance between theory and evidence is never linear, the edifice of

Yogi Hendlin

Hendlin@esphil.eur.nl

1 Fairbanks, AK, USA

2 Erasmus School of Philosophy, Erasmus University Rotterdam, Rotterdam, Netherlands

3 Dynamics of Inclusive Prosperity Initiative, Erasmus University Rotterdam, Rotterdam, Netherlands

4 Environmental Health Initiative, University of California, San Francisco, CA, USA 
theory historically outlives its usefulness - most of all, because theories are idealized versions of phenomena, attempting to jettison or neatly tie-up the loose ends of constantly updated and changing scientific understandings of reality. To what extent might the defenders of neo-Darwinism be victims of the sort of illusions they railed against?

The lack of interaction between the past paradigm (neo-Darwinism) and the ascendant Extended Evolutionary Synthesis, where the turf of new scientific discoveries has been most productive in providing new evidence supporting theory production in recent decades, could be viewed as a failure of the basic social mechanisms of civil disagreement. The academic world is not immune to the larger atmosphere of cultural polarization in which it operates and with which it must interact. The use of social pressure to shut out objectionable ideas can take many forms. But reluctance to engage in productive debate should be based on the merits (or lack thereof) of the arguments forwarded. Individual legacies should play no part in this decision. As we have witnessed, Lamarck himself has by turns been revered, derided, and reappraised. Legacies can easily be misappropriated regardless of original intentions.

Turning to these arguments, Noble cites sexual selection in support of the role of agency in evolutionary processes. Attesting to agency's role in evolutionary processes, we could add Amotz Zahavi's (1975) Handicap Principle, which states that when animals act altruistically, they handicap themselves - assuming a risk or enduring a sacrifice - to increase their own prestige within the group and thus signal their status (and fitness) as a partner or rival. This work was subsequently generalized as signal selection or signaling theory, similar to the virtue signaling we find in human societies. Richard Dawkins (2008) noted this novel form of selectionism in The God Delusion and elaboated upon it in a response to the 2008 Edge question "What have you changed your mind about? Why?" He writes:

Scientists actually gain kudos through changing their minds... I have changed my mind, as it happens, about a highly paradoxical theory of prestige, in my own field of evolutionary biology. That theory is the Handicap Principle suggested by the Israeli zoologist Amotz Zahavi. ...Maynard Smith couldn't find a mathematical model that led to the conclusion that Zahavi's theory might work. He left open the possibility that somebody else might come along later with a better model. That is exactly what Alan Grafen did, and now we all have to change our minds... Although I was wrong in my scepticism, and I have now changed my mind, I was still right to have been sceptical in the first place! We need our sceptics, and we need our Grafens to go to the trouble of proving them wrong.

Dawkins was by no means alone in his initial skepticism and subsequent adoption of ideas that had formerly been rejected concerning the role of agency in evolution. In an interview conducted in his later life Ernst Mayr (1997) reflected on how he ignored purposive activities in his early work because, as he frankly stated, "it bothered me." For years Mayr resisted the widespread role that agency plays throughout the community of life. Not only have our metaphors died and infected our ability to evaluate our conceptual understanding of evolution, as Noble points out, but our cultural entrainment may have also, to at least some nontrivial extent, influenced our willingness to revisit and assess these concepts (Knorr-Cetina, 1999). 
Agency, as a driver of evolution, has a long history, perhaps best outlined by Corning and Szathmáry (2015). In their account, agents enter into cooperative interactions, producing synergistic effects that become causes of differential selection. Regarding the mystery of agency, Dennett (2018) rhetorically asked "How can an aggregation of trillions of selfish, myopic cells discover the unwitting teamwork that turns that dynamic clump into a person who can love, notice, wonder, and keep a promise?" As if answering his question, he speculates with Levin and Dennett (2020) that selves can scale into a "superagent" and thereby extend their teleological capacity. They suggest that "the key dynamic" for this to occur is "access of agents to the same information pool" which "kickstarted the continuum of increasing agency." More than merely deterministic systems, agents have the capacity to anticipate causal processes and control their actions in light of some desired outcome. He noted that it is a mistake to "fail to attribute goal-directedness to a system that has it," calling this tendency "teleophobia." Accordingly, "teleophilia" might describe the tendency to attribute goal-directedness to such systems.

But which systems have agency? Noble cautions that our inability to "see" agency does not imply its absence. He suggests that agency is only present at the scale of "organisms and groups of organisms." By placing the biological agent and its teleonomic processes at the center of the evolutionary drama, rather than the gene, Noble provides a new vantage to understand some incompletely explained phenomena. For example, during horizontal gene transfer some bacteria are capable of "harpooning" DNA in their surrounding environment to speed up their evolution (Ellison et al., 2018). From a gene-centric view of life, such activities are difficult to account for. Notably, Dawkins' concept of an extended phenotype does accommodate organisms' modification of their own selection pressures (e.g., through niche construction). Such extensionism, however, pushes against the limits of both gene- and organism-centric views, throwing into question even the notion that there exists a fixed unit of selection. These realist perspectives have enormous instrumental value, but provide incomplete theories of evolution with mounting remainders. Empirical observation reveals a network of supervening interactions and distributed agencies, operating at multiple scales, selecting for processes and relationships over objects and units (Hendlin, 2016).

Noble next turns his analysis to how, by means of a few physically tractable processes, cells devised a way to overcome the danger of entropic decay and achieve the high level of structural stability required for DNA molecules. His detailed description of these molecular structures and processes, required to ensure minimal errors during replication, intersects with a much larger conversation about how agency and consciousness arises from its physical substrates, and whether or to what degree those can be substituted without impinging upon the processes themselves (Cobb, 2020). So when Noble cautions "It is a mistake to represent all biological information as digital," this should be read as a cautionary warning about the computational metaphor, whose central conceit is to ignore the physical substrate (Ferretti \& Adornetti, 2014).

\section{A Figure-Ground Shift}

Noble reexamines the paradigm through which we view evolutionary processes. Noble introduces his principle of biological relativity, eschewing a privileged position of 
analyzing life and forcing a reexamination of the paradigm through which we view evolutionary processes. Here biosemiotics is especially useful. Life is an emergent phenomenon, Noble writes: "If you isolated all the components, there would be no oscillator [maintaining the heart's rhythm]." We must consider the organism in its entirety. Biosemiotics goes further and insists we must consider the organism and environment (Umwelt), as the unit of analysis - extending up to and including a world of biosemiotic relationships (Jesper Hoffmeyer's (1998) semiosphere). This conceptual reversal is described as a figure-ground shift by Fritjof Capra (1997). Bruno Latour $(2017,104)$ has similarly mused, "if there is no selfish gene, it is literally because the self has no limit" (within that self's Umwelt, we should add). Moving our attention from objects to relationships, from nodes to edges, and from isolation to integration effectively dissolves the distinction between object boundaries and relationship links into a dynamic network poised "on the boundary between order and chaos" (Kauffman, 1993). And here we see relation in the reality of its suprasubjective character, "the conditio sine qua non for achieving an understanding of semiosis" (Deely, 2015, 267).

Noble's emphasis on relational, material, and agentic processes puts him in the middle of many active debates within communities contributing to the growth of network science, which has been making significant contributions to numerous fields, not the least of which biology and ecology (Papale et al., 2020). One might say he is knocking on the door of the hard problem of consciousness through the exploration of semiotic and process- relational ontologies (Ivakhiv, 2017), offering us new ways to engage with these conceptual tools whose implications lend credence to Peirce's synechism (Esposito, 2005). Noble states, "it is difficult to break out from the compelling model that [the Modern Synthesis] forms of the world;" but fortunately, as in physics (Candiotto, 2017), we are now beginning to see a figure-ground shift occurring in biology and the foundations of an alternate paradigm being laid with accumulating evidence.

This shift in biological sciences occurs simultaneous to a perspectival shift in understanding the cultural and material conditions that gave rise to the Anthropocene. For an example of how existing cultural conditions have been reinforced, anthropologists Brian Hare and Vanessa Woods' (Hare \& Woods, 2020) book Survival of the Friendliest emphasizes how the individualistic metaphors that have come to caricature Darwinism within the popular mind are not only empirically false, but also corrosive to the values of a healthy society. "Survival of the fittest" (originally Herbert Spencer's term, not Darwin's), has been misconstrued as cutthroat competition, though as we are coming to learn, forms of cooperation tend to be the most successful strategies (Henrich \& Henrich, 2007). Other forms of group selection in addition to kin-selection including evidence for holobiont selection - emphasize that formerly overlooked phenomena may have been simply unnoticed due to cognitive biases attached to an unfortunate misinterpretation of Darwin's theory of selection (Miller et al., 2019). But if we are to transition to some form of an ecological civilization this century (as Arran Gare (2016) argues we must), then we will need to recognize such misinterpretations, uprooting and replacing the illusions of hyper- individualism and agency-less determinism born of the "dead metaphors" that have gained underserved currency within Neo-Darwinism. In their place we must cultivate a wider public understanding of the biological and evolutionary processes that have hitherto been excluded from our models - including the networks of relationality and the agentic, proof-correcting 
processes Noble describes. Such accounts not only are more faithful to the available evidence concerning the growth and development of life, at all spatiotemporal scales, but are also capable of informing a philosophical perspective that, in comparison with our hitherto dominant view of Neo-Darwinism, certainly serves as a better foundation for an ecological civilization.

Noble's criticisms of Dawkins and the other contributors to the dominant understanding of evolution in the form of the Modern Synthesis reminds us how contemporary agroecologists tend to view Norman Borlaug and other architects of the Green Revolution. In each case, these people faced considerable problems and attempted to solve them in the best way they could with the tools and information at hand. Those accomplishments are praiseworthy and yielded an abundant harvest according to their chief measurement, but new evidence shines harsh light on their omissions, which have become more glaring and ecologically devastating with the passage of time. The more deeply we have instituted these mechanistic inventions and interventions, the more glaring the gap between the real and the ideal has become in the material form of waste (Serres, 1995). To address the challenges of the Anthropocene, we can no more continue to apply insufficient theories of evolution to elucidate the living processes of our planet than we can continue the harmful practices of industrial monocrop agriculture supported by petrochemical inputs. Judging by the direction of contemporary scholarship, there is already a figure-ground shift underway: a move from teleophobia toward the integrated agent, a holobiont that constructs not only its niche but also its future.

Open Access This article is licensed under a Creative Commons Attribution 4.0 International License, which permits use, sharing, adaptation, distribution and reproduction in any medium or format, as long as you give appropriate credit to the original author(s) and the source, provide a link to the Creative Commons licence, and indicate if changes were made. The images or other third party material in this article are included in the article's Creative Commons licence, unless indicated otherwise in a credit line to the material. If material is not included in the article's Creative Commons licence and your intended use is not permitted by statutory regulation or exceeds the permitted use, you will need to obtain permission directly from the copyright holder. To view a copy of this licence, visit http://creativecommons.org/licenses/by/4.0/.

\section{References}

Candiotto, L. (2017). 'The reality of relations' Giornale di Metafisica., 2(2017), 537-551.

Capra, F. (1997). The web of life: A new scientific understanding of living systems (unknown edition.). Anchor. Cobb, M. (2020). The idea of the brain: The past and future of neuroscience (Illustrated edition.). Basic Books.

Corning, P. A., \& Szathmáry, E. (2015). "Synergistic selection": A Darwinian frame for the evolution of complexity. Journal of Theoretical Biology, 371, 45-58. https://doi.org/10.1016/j.jtbi.2015.02.002.

Dawkins, R. (2008). A flip-flop should be no handicap. The Edge. https://www.edge.org/response-detail/ 10154. Accessed 12 March 2021.

Deely, J. (2015). Objective reality and the physical world: Relation as key to understanding semiosis. Green Letters, 19(3), 267-279. https://doi.org/10.1080/14688417.2015.1063239.

Dennett, D, C. (2018). What is the last question? The Edge. https://www.edge.org/response-detail/27449. Accessed 12 March 2021. 
Ellison, C. K., Dalia, T. N., Vidal Ceballos, A., Wang, J. C.-Y., Biais, N., Brun, Y. V., \& Dalia, A. B. (2018). Retraction of DNA-bound type IV competence pili initiates DNA uptake during natural transformation in Vibrio cholerae. Nature Microbiology, 3(7), 773-780. https://doi.org/10.1038/s41564-018-0174-y.

Esposito, J. (2005). Synechism: The keystone of Peirce's metaphysics. In The Commens Encyclopedia: The Digital Encyclopedia of Peirce Studies. http://www.commens.org/encyclopedia/article/esposito-josephsynechism- keystone-peirce\%e2\%80\%99s-metaphysics. Accessed 30 March 2021.

Ferretti, F., \& Adornetti, I. (2014). Against linguistic Cartesianism: Toward a naturalistic model of human language origins and functioning. Language \& Communication, 37, 29-39. https://doi.org/10.1016/j. langcom.2014.04.003.

Gare, A. (2016). The philosophical foundations of ecological civilization: A manifesto for the future (1st ed.). Routledge.

Hare, B., \& Woods, V. (2020). Survival of the friendliest: Understanding our origins and rediscovering our common humanity (First edition.). Random House.

Hendlin, Y. H. (2016). Multiplicity and welt. Sign Systems Studies, 44(1/2), 94. https://doi.org/10.12697/SSS. 2016.44.1-2.06.

Henrich, N., \& Henrich, J. P. (2007). Why humans cooperate: a cultural and evolutionary explanation. Oxford University Press.

Hoffmeyer, J. (1998). The Unfolding Semiosphere. In G. van de Vijver, S. N. Salthe, \& M. Delpos (Eds.), Evolutionary systems (pp. 281-293). Springer Netherlands. https://doi.org/10.1007/978-94-017-1510-2 21.

Ivakhiv, A. (2017). On a few matters of concern: Toward an ecology of integrity. In S. Mickey, S. M. Kelly, \& A. Robbert (Eds.), The variety of integral ecologies: Nature, culture, and knowledge in the planetary era. SUNY Press.

Kauffman, S. A. (1993). The origins of order: Self-organization and selection in evolution (1 edition.). Oxford University Press.

Knorr-Cetina, K. (1999). Epistemic cultures: How the sciences make knowledge. Harvard University Press.

Latour, B. (2017). Facing Gaia: Eight Lectures on the New Climatic Regime (1 edition.). Polity.

Levin, M., \& Dennett, D. (2020). Cognition all the way down. Aeon. https://aeon.co/essays/how-tounderstand-cells-tissues-and-organisms-as- agents-with-agendas. Accessed 12 March 2021.

Mayr, E. (1997). Changing ideologies: teleology. https://www.youtube.com/watch?v=XjF4E2z-dlo. Accessed 12 March 2021.

Miller, W. B., Torday, J. S., \& Baluška, F. (2019). Biological evolution as defense of "self.". Progress in Biophysics and Molecular Biology, 142, 54-74. https://doi.org/10.1016/j.pbiomolbio.2018.10.002.

Noble, D. (2021). The illusions of the modern synthesis. Biosemiotics. https://doi.org/10.1007/s12304-02109405-3.

Papale, F., Saget, J., \& Bapteste, W. (2020). Networks consolidate the core concepts of evolution by natural selection. Trends in Microbiology, 28(4), 254-265. https://doi.org/10.1016/j.tim.2019.11.006.

Serres, M. (1995). The natural contract. University of Michigan Press.

Zahavi, A. (1975). Mate selection-A selection for a handicap. Journal of Theoretical Biology, 53(1), 205214. https://doi.org/10.1016/0022-5193(75)90111-3.

Publisher's Note Springer Nature remains neutral with regard to jurisdictional claims in published maps and institutional affiliations. 